\title{
AN INTERNATIONAL PERSPECTIVE ON TEACHING ITALIAN LANGUAGE AND CULTURE
}

The research has demonstrated the contemporary and effective methods of teaching Italian in Ukraine. To use a foreign language proficiently means to perceive, understand, and ultimately imitate another culture in an accurate and truthful fashion. Teaching the language in the right manner should both mirror a culture in terms of its language and customs. The educator should depict more average character types who use less elevated

language and more physical gestures for self-expression as it is common for Italian culture. It is this combination of accessible language and visual conceptual immediacy that makes it so suitable for the foreign language learning and so invaluable for inter-cultural appreciation at different levels of instructions. Most of the educators teach Italian as a foreign language at the university, but some teach culture as well, which includes both linguistic and extra linguistic competence, or teach at other levels. They provide a coherent and organized overview of contemporary Italian pedagogy, using case studies in the fields of language methodology and language acquisition from Italy and four major countries where there is a strong tradition of teaching Italian.

The main topics include teaching learnable grammar, podcasting and iPod in teaching and learning the Italian language, but at Kiev national universities the priority is given to the communicative approach, life situations. The importance of adopting a didactic translation methodology in the context of the 21 century university reform, building an intercultural identity in a cross-cultural transition, using films at all levels of proficiency, and the history of Italian culture retold by protest songs is being analyzed. This article discusses a series of considerations that underpin the design of a language and culture curriculum at lower level. These reflections are focused on the following areas: environments, text, culture and language, language and culture, authenticity. They are the result of several weeks of intensive online discussions and exchanges between different higher institutions in Ukraine.

Key words: teaching Italian language, international perspective, contemporary Italian pedagogy, new methodology, university reform, intercultural identity.

Introduction. Italian national security rests on our commitment to educate and prepare our youth for active engagement in the international community. We call on schools, teachers, students, parents, and community leaders to promote understanding of our nations and cultures by encouraging our young people to participate in activities that increase their knowledge offing foreign languages and appreciation for global issues, history, geography, literature, and the arts of other countries. We may mention now the importance of existence of integrated, effective and coherent foreign language programs at higher establishments that can prepare students for international and negotiation-based environments.

The urgency of the problem. Unfortunately, the present economic crisis fostered the review of particular second language curricula and programs in Ukraine. The resulting decrease in funding teaching and learning is also further aggravated by the fact that language instruction is not always a core curricular subject especially Italian as a second foreign language. Despite these negative factors, the number of tertiary students enrolling in Italian and Spanish programs has, in the course of the last ten years, grown in Ukraine. Further, a renewed sensitivity towards pedagogical topics behind foreign language teaching and learning inspired academics to embark on various degrees of curriculum reforms - some of them supported by the academic institutions, most steered by individuals or foreign language departments.

The scientific results and their discussion. According to a new study conducted by the Italian Ministry of Foreign Affairs, the importance of learning the Italian language is growing all over the world. To the group of those who learn it for personal satisfaction, mainly for cultural reasons, is added the growing number of those who decide to learn it for study and work reasons. In recent days the Italian language is not taught in the preuniversity system from the third grade of the elementary school to the twelve grade of the high school which are public but the vocational educational schools provide with the following choice.

It is also worth to mention that the Italian language courses are offered to people who want to study or work in Italy, without excluding anyone, and by thus including all those who are interested in learning the Italian language through courses starting from children aged 5 to teenagers aged 11 to 14 years, or for students aged 17 and 18, who actually make up the majority of those who go to study in Italy.

Students take courses for level $\mathrm{C} 1$ or $\mathrm{C} 2$ which are the highest levels in the Italian language. Or those, who want to take A1 or A2 level language courses, when the time comes to go to study in Italy they must have achieved the minimum level of B2 in order to be accepted in the Italian Universities. 
Those who receive the certificate of the Italian language acknowledgment in Ukraine go to Italy to study and not to be employed. Others who have attended the Italian language courses at the Italian Institute of Culture and have received different certificates have had the chance to be employed in some Italian enterprises in Ukraine. What it helps the Ukrainian students when they receive the Certificate of Acknowledgement of the Italian language at this Institute is that it is easier for them to get integrated into the Italian society and to properly cope with the study. The teaching process of the foreign language has combined the humanist tradition and the scientific knowledge, providing not only the education of students who will be able to successfully pursue their studies in Ukraine or the Italian Universities, but also to become a connecting bridge in the relations between the two countries and the two cultures, so that after their university graduation they can work in a European context. The Italian Ministry of Foreign Affairs promotes the dissemination of the Italian language in Ukraine through the Italian-Ukrainian foreign sections in the high establishments of Ukraine. The level of knowledge of the Italian language in high school admission must be at least $\mathrm{Bl}$ but it is still needs to be improved. For the subjects such as: the Italian language and literature, history of world civilization, mathematics and physics, the teaching is carried out by teachers and sometimes native speakers and Italian unabridged texts, which are discussed by students in class. The first foreign languages taught in the Ukrainian public schools are: English, French, German and Italian, in which the percentage of the students, who learn foreign languages in Ukrainian Public schools, is: $49 \%$ English, $6.3 \%$ Italian. The Italian Language in the vocational schools is also becoming popular these days. The Italian language teaching has also been considered as a priority in the vocational schools. To this aim, it has been believed to enrich the school programs of our vocational schools with Italian language courses intending to implement new methods of teaching both language and culture. It can be noted that the tendency is growing and in this sense it is right for the Italian party to undertake initiatives for teachers' trainings as well as for financing for the supply of materials and in general for activities at schools.

The Department of Italian Language Studies has numerous cooperation agreements with Italian universities such as Inter-University Consortium ICON and other foreign organizations operating in the dissemination of the Italian language such as "Dante Alighieri". It is also equipped with a rich library and a computerized laboratory and the presence of the Italian lecturers is secured with the continuous support of the Italian Foreign Ministry. This department suggests a 3-year diploma course of the first cycle of studies in the Italian language and culture and a Master of Science degree course of the second cycle of studies specialized in three areas: The didactics of the foreign language - with the diploma title- "Teacher of the Italian language"; "Translation and Interpretation"; and "Language and Intercultural Communication and Tourism". "BA in the English and American Studies" "BA in the German Philology" "BA in the Italian Language and Culture", "BA in the French language and culture." Professional Master in "Translation and interpretation of the German language".

It can be mentioned and generalized that the sociolinguistic situation in Ukraine in the last decade has undergone significant changes making the Italian language have a strong penetration not only to the cognitive level of the Ukrainian population but also to its didactic level into the Ukrainian education system highlighting the natural disposition of the Ukrainian people toward the Italian language acquisition and as a good opportunity to further approach the Europe, in which they wish to integrate.

It is a pity that little or no recent literature exists on the integration of culture and language in Italian study course. Only a handful of papers engage with concepts of culture and language and attempt to define an approach or pedagogy for the integration of the two in Italian L2 environments $[1 ; 2 ; 3]$. The most insightful and extensive discussion on the relationship and integration of language and culture in foreign language programs can be found in the series of articles published together in The Modern Language Journal, issue number two of volume 92, published in 2008. More widely, and by contrast, there is a growing literature on pedagogy for ab initio tertiary programs $[4 ; 5 ; 6]$. The full work has been conducted on the earliest levels of instruction by L2 German scholars [7].

As a result, the present article represents an attempt to bring the Italian L2 literature into beneficial conversation with research in other languages. 'Languaculture' is the term Michael Agar uses to describe the integration of culture and language within a socio-collaborative environment in second language teaching and learning [8]. Recent literature [9; 10] (Laurillard; van Lier) on this topic - and its challenges-argues that blended environments offer the most flexible and comprehensive way to link "culture or content of a second language / cultural area with second language learning" [11] (Byrnes 2009, quoted above). In a blended environment learners can develop both the interpersonal communicative skills and academic literacy-normally developed in the more advanced stages of learning 'Blended learning' has a very broad meaning [12] and encompasses several different teaching practices, technologies and theories.

The aim of this paper is to join together the following sets of ideas and highlight the main techniques for teaching Italian language and culture.

The following scientists made a great effort on the way to improve the Pedagogy in teaching Italian: Kramsch, Whiteside, Willis, Nunan, Johns and others. Let's take a deeper look at their theory and practice. They have highlighted the main elements which should be taken into consideration. Let's take a deeper look at the scientific inversigations. 
-Theories: socio-cultural and socio-constructivist theories of L2 [13]. The teaching and learning of L2 is situated within a community of practices and meaning-making processes (Lave and Wenger; Kramsch 2002) in which learners are able to communicate in the language of a community and to act according to its norms [14].

Pedagogies: task-based [14], content-based (Aski and Webb 13-16; also Rodgers) and text and genre based.

-Spaces: classroom and virtual spaces such as email, facebook and learning management tools.

-Texts: preference for 'authentic' audio and visual texts and materials that can be available through different environments (synchronous and asynchronous) to the pre-packaged textbook.

Roles: teachers and learners share the objectives and approaches in a more learner-centred teaching environment. The teacher becomes as a facilitator and has the role of identifying authentic tasks, simplifying them if necessary and training students to develop their analytical and "define the structure of learning required to achieve that task".

A blended and integrated curriculum takes into account the teacher's and learner's responsibilities, institutional agendas and management beyond the classroom by offering an environment that can easily adapt to change and diversity. The ideal L2 environment for students and teachers is the one that allows for negotiation of the curriculum's content through an ongoing collaboration between students and teachers together with an integrated pedagogy that focuses on the development of the learner's cognitive and collaborative skills. This article outlines the main design and development of the authentic materials with the aim of achieving an optimal mix between in-class and out-of-class learning in the context of teaching Italian language and culture at Ukrainian university. The research discusses three aspects in relation to the following themes: (a) conceptions of the in-class/out-of-class activities, (b) the pedagogical necessity for out-of-class creative materials development, (c) the nature of the language-learning materials required for different technologies, and (d) the concomitant demands on the language-teacher-developer. The three projects could be realized throught: (a) Italia oggi, a videodisc-based facility for self-access work with television news; (b) the Italian SMS project, a mobile learning project using bulk text messaging; and (c) La mensa, a class blog designed to support reading and writing practice. The recent situation proves that all these materials need to be implemented these days and developedand the role of the teacher-as- materials-developer - need to be observed and extended wider with the great range of technologies currently in use. This has major implications for teacher education and learner training in the new school. Language teaching, suggested the development of two kinds of materials: the basic traditional which highlight the main core aspects of the course and new creative materials to serve as "guidelines or frameworks for the learners' use of the foreign professional communicative competence. This general framework for our understanding of the new materials is helpful particularly now, when we need to expand our conception of the new school in the 21st century, not only because of the increasing number of technologies that are now in use, but also because of a diversity of function that reaches well beyond the conventional computer tutor. For example, developing contemporary materials using Web 2.0 technologies such as blogs and wikis is very much concerned with structuring and activating a process. Such new process materials segment, mediate, and help manage-both implicitly and explicitly-the interactions between students, teachers, and the computer in different ways from earlier approaches. The implementations of the communicative methods are of great importance for fluency and communicative interaction. They should be based on:

1. Language grounded, teaching the foreign language through communication. Communicative approach was first based on the theory that teaching communication is possible only by means of communication. Which means that the main part of the class should be oriented on speaking? It is necessary to mention that communication itself is the main educational condition. The speaking is not only declaration, being the simple addition to teaching process, but also serves: a) a channel, which provides with knowledge; b) the way, which develops individuality; c) the educational instrument of the necessary personality traits; d) the way of experience transition and possibility of speaking in the right manner.

2. Functioning. This approach gives the understanding, first of all, helps to realize by students the functional aspects of the language, so every student should understand the personal value of the practical language skills. Language activity has three directions: lexical, grammatical and phonetical. They are connected closely with one another in the speaking process. The conclusion is that words are impossible to learn out of the context. Functioning helps to understand that both words and grammar forms are remembered at once in action: the student chooses any language task - proves his opinion, has doubts in what he has heard, asks about something, forces for interaction and at the same time learning the necessary words or grammar forms. The following proves that functioning appears not as separated language techniques but functions provided by them. The materials and their structure depend on the functions expressed by students.

3. Situations. In other words this is the role organization of the educational process. The communicative study is provided by means of situations, which is understood as a system of relations. It is very important to have a close look at choosing and organization of materials based on situations and problem conversational topics which could be interesting for different students age groups. The situation exists as the integrative dynamic system of socio, role, active and moral interaction between the speaking audiences. It is the universal 
form of the teaching process function and serves as the way of organization, their presentation, motivation of speaking activity, the main condition of communicative skills development.

Conclusions. We have mentioned that the design and way of teaching Italian language and culture needs further discussion and new materials.

The materials development landscape is marked now by its range and diversity. The reasons are many, but two key factors most certainly arise: (a) the increasing number of generic technologies available which can be used to facilitate and encourage interaction between the teacher and students and among students themselves across the in-class/out-of-class divide and (b) students' and teachers' increased proficiency in the use of the technologies. These two factors have meant that we now have the means and the skills to enhance and perhaps intensify the in-class/out-of-class relationship.

However, in spite of all this, it is still necessary to seek the optimal in-class / out-of-class mix materials for teaching Italian to intensify speaking and improve the level of the foreign communicative competence. This still is, and perhaps always will be, a work in progress because, as Jim Pusack and his colleagues pointed out many years ago (Hope, Taylor \& Pusack, 1984), ultimately it all depends upon the teacher. Without the pivotal role played by the language teacher in developing new century materials and orchestrating their implementation, the potential of an engaging, powerful language-learning environment breaks down. The demands on the teacher are becoming even more intensive compared with the early days of teaching Italian language and culture in Ukraine, partly because the expectations of the student body are now much more sophisticated and demanding.

They also invoke the need for a rich institutional and technical support structure, and also learner training so that learners can distinguish between using generic technologies for learning as opposed to social purposes. Although, again, much learner training may come back to the work of the language teacher in class, perhaps there are avenues for increased learner training to be conducted through tutorial software out of class, in larger groups beyond the individual class, or even across language-learning programs. These factors are particularly important if we wish to avoid the novelty trap in class and want the student experience to be engaging and sustained over the long term. In all of this, still, locating the ideal in-class / and out-of-class mix and the teacher's role are critical.

\section{REFERENCES}

1. Ciccarelli Andrea "Teaching Culture through Language: Suggestions for the Italian Language Class"/ Andrea Ciccarelli. - Italica 73.4 (1996). - Pp. 563-576.

2. Rodgers Daryl M. "Developing Content and Form : Encouraging Evidence from Italian Content-Based Instruction" / Daryl M. Rodgers // The Modern Language Journal. - 90.3 (2006) - Pp. 373-386.

3. Diadori Pierangela Insegnare I'italiano a Stranieri / Pierangela Diadori. - Florence : Le Monnier, 2001

4. Leder Gabriela Ab Initio Language. A Guide to Good Practice in Universities and Colleges / Leder Gabriela, G. Reimann, and Riana Wash // The Example of German. - London : Centre for Information on Language Teaching and Research (CILT), 1996.

5. Risager Karen "Languaculture as the Key Concept in Language and Culture Teaching" / Karen Risager // The Consequences of Mobility ; [Ed. B. Preisler, A. Fabricius et al.]. Roskilde : Roskild, 2005. - Pp. 185-196.

6. Swaffar Janet Reading for Meaning: An Integrated Approach to Language Learning / Janet Swaffar, Katherine Arens, Heidi Byrnes. - Englewood Cliffs, NY : Prentice- Hall, 1991.

7. Trude Helf "Student Modeling and Ab Initio Language Learning"/ Helf Trude, Mathias Schulze // System. 31.4 (2003). - Pp. 519-535.

8. Agar Michael Language Shock : Understanding the Culture of Conversation / Michael Agar. - New York : Morrow, 1994.

9. Laurillard Diana Rethinking University Teaching : A Conversational Framework for the Effective Use of Learning Technologies / Diana Laurillard. - London : Routledge Falmer, 2002.

10. Lier Leo van "An Ecological-Semiotic Perspective on Language and Linguistics" / Lier Leo van // Language Acquisition and Language Socialization : Ecological Perspectives. - Ed. Claire Kramsch. London: Continuum Press, 2002. - Pp. 140-164.

11. Byrnes Heidi "Systemic-Functional Reflections on Instructed Foreign Language Acquisition as Meaning-Making : An Introduction / Heidi Byrnes //" Linguistics and Education. - V. 20 (2009). - Pp. 1-9.

12. Carroli Piera Literature in Second Language Education: Enhancing the Role of Texts in Learning / Piera Carroli. London and New York : Continuum, 2008

13. Kramsch Claire Language Acquisition and Language Socialisation : Ecological Perspectives / Claire Kramsch. London : Continuum, 2002

14. Willis Jane A Framework for Task-Based Learning / Jane Willis. - London : Longman, 1996.

\section{Стебаева О. В. Международный взгляд на преподавание итальянского языка и культуры.}

Исследование сосредоточено на современных и эффективных методах преподавания итальянского языка в Украине. Владение иностранным языком на высоком уровне означает получить глубокие знания, понять и, наконеи, имитировать другую культуру точно и метко. Обучение языку на высоком уровне должно отражать культуру, с точки зрения ее языка и обычаев, и наличие высокого уровня 
коммуникативной компетентности. Педагог должен изображать более типичные черты характера, присущие этой культуре, использовать более применяемую лексику и больше физических жестов для самовыражения, присущзи для итальянской культуры. Именно такая комбинация доступного языка и визуальной концептуальной непосредственности делает его таким пригодным для изучения иностранного языка и потому бесценно для межкультурной оценки на разных уровнях. Большинство преподавателей преподают итальянский как иностранный язык в университете, однако некоторые также обращают внимание на элемент культуры во время освоения языка, включает в себя лингвистическую и экстралингвистическую компетентность, или учат на других уровнях.

Большинство преподавателей преподают итальянский как иностранный язык в университете, однако некоторые также обращуат внимание на элемент культуры во время освоения языка, что включает в себя лингвистическую и экстралингвистическую компетентность, или учат на других уровнях. Они обеспечивают согласованный и организованный обзор современной итальянской педагогики с использованием тематических исследований в сферах языковой методологии и собственно изучение итальянского языка и четырех основных стран, где существует сильная традиция преподавания итальянского языка. Основные темы включают в себя преподавание грамматики, Podcast и iPod в обучении и изучении итальянского языка, однако в Киевском национальном университете приоритет отдается коммуникативному подходу, рассмотрению жизненных ситуаций. В работе проанализированы важность применения методологии дидактического перевода в контексте реформ университетского университета 21 века, построения межкультурной идентичности в межкультурном переходе, использованием фильмов на всех уровнях изучения и восприятия истории итальянской культуры. В данной публикации рассматривается ряд соображений, которые лежат в основе разработки учебной программы по языку и культуре Италии на начальном уровне. Эти размышления ориентированы на следующие сферы: среда, текст и культура, язык, язык и культура, подлинность. Они являются результатом нескольких недель интенсивных онлайновых дискуссий и обменов между выстими учебными заведениями Украины.

Ключевые слова: преподавание итальянского языка, международные перспективы, современная итальянская педагогика, новая методология, университетская реформа, межкультурная идентичность.

\section{Стєбаева О. В. Міжнародний погляд на викладання італійської мови та культури.}

Дослідження зосереджене на сучасних та ефективних методах викладання італійської мови в Україні. Володіння іноземною мовою на високому рівні означає отримати глибокі знання, зрозуміти $i$, нарешті, імітувати іншу культуру точно та влучно. Навчання мові на високому рівні має відображати культуру, з точки зору ї̈ мови та звичаїв, та наявність високого рівня комунікативноі компетентності. Педагог повинен зображувати більш типові риси характеру, які притаманні иій культурі, використовувати

більш вживану лексику та більше фізичних жестів для самовираження, щьо є притаманним для італійської культури. Саме така комбінація доступної мови та візуальної концептуальної безпосередності робить його таким придатним для вивчення іноземної мови і тому безцінне для міжкультурної оцінки на різних рівнях. Більшість викладачів викладають італійську як іноземну мову в університеті, однак деякі також звертають увагу на елемент культури під час опанування мови, щзо включає в себе лінгвістичну та екстралінгвістичну компетентність, або навчають на інших рівнях.

Вони забезпечують узгоджений та організований огляд сучасної італійської педагогіки з використанням тематичних досліджень у сферах мовної методологї та власне вивчення Італії, мови та чотирьох

основних краӥн, де існує традиція викладання італійськой мови. Основні теми включають в себе викладання граматики, Podcast та іPod у навчанні та вивченні італійської мови, проте в Київьких національних університетах пріоритет надається комунікативному підходу, розгляду життєвим ситуаціям. У роботі проаналізовано важливість застосування методологї дидактичного перекладу в контексті реформ університетського університету 21 століття, побудови міжкультурної

ідентичності в міжкультурному переході, використанням фільмів на всіх рівнях вивчення та сприйняття історії італійської культури. У даній публікаціі розглядається низка міркувань, які лежать в основі розробки навчальної програми з мови та культури Італіі на початковому рівні. Ці

роздуми орієнтовані на такі сфери: середовище, текст та культура, мова, мова та культура, автентичність. Вони є результатом декількох тижнів інтенсивних онлайнових дискусій та обмінів між вищими навчальними закладами України.

Ключові слова: викладання італійськоі мови, міжнародні перспективи, сучасна італійська педагогіка, нова методологія, університетська реформа , міжкультурна ідентичність. 